\title{
Evaluation of acute cardiorespiratory and hemodynamic changes in perioperative intravenous antimicrobial applications in cats
}

[Avaliação das alterações cardiorespiratórias e hemodinâmicas agudas em aplicações pré-operatórias de antimicrobianos, pela via intravenosa, em gatos]

P.R.S. Gomide ${ }^{1}$, R.C. Costa ${ }^{1}$, L.G. Faria ${ }^{1}$, J.T. Brondani ${ }^{2}$, A.P. Gering ${ }^{1}$, A. Escobar ${ }^{1}$, B.P. Santarosa ${ }^{3}$, B.W. Minto ${ }^{1}$

\author{
${ }^{1}$ Faculdade de Ciências Agrárias e Veterinárias - Universidade Estadual Paulista - Jaboticabal, SP \\ ${ }^{2}$ Médica veterinária autônoma - Curitiba, PR \\ ${ }^{3}$ Instituto de Ciências Agrárias - Universidade Federal dos Vales do Jequitinhonha e Mucuri - Unaí, MG
}

\begin{abstract}
The metabolic peculiarities of felines favor an intoxication. Fifty healthy female cats were divided into five groups: PG (placebo group), G2 (cefazolin), G3 (ceftriaxone), G4 (enrofloxacin) and G5 (ampicillin) were used. The parameters evaluated were: total expired carbon dioxide $\left(\mathrm{ETCO}_{2}\right)$, oxygen saturation in hemoglobin $\left(\mathrm{SpO}_{2}\right)$, heart rate (HR), respiratory rate (RR), body temperature (BT), systolic, mean and diastolic blood pressure (SBP, mBP and DBP) by invasive method, at T0, 5 (T5), 10 (T10), 15 (T15), 20 (T20), 25 (T25) and 30 (T30)minutes after administration of the treatments. HR presented reduction in G2 compared to PG at all times, except T20, and in G4, T25 and T30 were lower than the T0 values $(\mathrm{P}<0.05)$. BT showed increase in the $\mathrm{G} 3$ at $\mathrm{T} 0$ and $\mathrm{T} 5$ and all groups showed reduction in the values of BT relative to T0 $(\mathrm{P}<0.05)$. $\mathrm{ETCO}_{2}$ increased in $\mathrm{G} 2$ and $\mathrm{G} 5$ at all times compared to $\mathrm{PG}(\mathrm{P}<0.05)$ and there were no differences among the times within each group. It was concluded that ceftriaxone is safer for the prophylactic antimicrobial use in cats, however the other antimicrobials are also indicated, because all the parameters, in all groups, basically did not change over the study and when this occurs it remains in reference interval.
\end{abstract}

Keywords: anesthesia, antibiotic, adverse effect, felines, hemodynamic

\section{RESUMO}

As peculiaridades metabólicas dos felinos favorecem quadro de intoxicação. Foram utilizadas 50 gatas saudáveis, que foram divididas em cinco grupos: GP (grupo placebo), G2 (grupo cefazolina), G3 (grupo ceftriaxona), G4 (grupo enrofloxacina) e G5 (grupo ampicilina). Os seguintes parâmetros foram avaliados: dióxido de carbono expirado $\left(\mathrm{ETCO}_{2}\right)$, saturação de oxigênio na hemoglobina $\left(\mathrm{SpO}_{2}\right)$, frequência cardíaca $(F C)$, frequência respiratória $(F R)$, temperatura corporal $\left(T^{\circ} C\right)$, pressão arterial sistólica,média e diastólica (PAS, PAM e PAD), pelo método invasivo, em 0 (T0), 5 (T5), 10 (T10), 15 (T15), 20 (T20), 25 (T25) e 30 (T30) minutos após a administração dos tratamentos. A FC apresentou redução no G2 em relação ao GP em todos os momentos, exceto no T20, e, no G4, o T25 e o T30 foram inferiores aos valores do TO $(P<0,05)$. A $T^{\circ} \mathrm{C}$ apresentou aumento no $G 3$ no T0 e no T5, e todos os grupos apresentaram redução nos valores da $\mathrm{T}^{\circ} \mathrm{C}$ em relação ao $\mathrm{TO}(P<0,05)$. O $\mathrm{ETCO}_{2}$ apresentou aumento no G2 e no G5, em todos os momentos, em relação ao GP $(P<0,05)$. Concluiu-se que a ceftriaxona é mais segura para uso profilático em gatos, entretanto os outros antibióticos também são recomendados, pois todos os parâmetros praticamente não se modificaram e, quando alterados, mantiveram-se dentro dos padrões de referência.

Palavras-chave: anestesia, antibiótico, efeito adverso, felinos, hemodinâmica

Recebido em 4 de março de 2020

Aceito em 23 de setembro de 2020

E-mail: pagomide@terra.com.br 


\section{INTRODUCTION}

Hospital-acquired infections, also known as nosocomial infections, are important clinical conditions due to their common occurrence and high morbidity and mortality rates (Ratti and Souza, 2009). These infections are related to invasive and non-invasive hospital procedures, as well as the surgery itself (Santos et al., 2012).

The prophylactic use of antimicrobials is one of the most important measures adopted to control the incidence of infections at the surgical field (Langer, 2009). Their benefits are universally accepted; however, their use can be controversial, especially in elective clean surgeries, as it promotes the indiscriminate use of these drugs and consequent bacterial resistance and unnecessary costs (Busk et al., 2010). Nevertheless, patients at high risk of acquiring infections can benefit from the high and fast plasma levels obtained by intravenous antimicrobial therapy (Nascimento et al., 2003).

The metabolic peculiarities of cats make them more prone to intoxication than other animals (Souza, 2003). The different hepatic pathways of drug metabolism and hemoglobin structure, which can oxidate into methaemoglobin, are the main culprits in the majority of adverse reactions and cases of intoxication in this species (Souza and Amorim, 2008). Despite the many clinical manifestations regarding the adverse effect of sub-acute, medium, and long-term use of antimicrobials in small animals, few reports are available on these drugs. Fewer still are the reports on their immediate effect when given intravenously, which could potentially interfere with the hemodynamic and respiratory stability of patients, especially cats (Moorer et al., 2013). It has been hypothesized that intravenous use of antimicrobials in cats can cause cardiorespiratory and/or hemodynamic alterations immediately after administration. Thus, the aim of this study was to compare the cardiorespiratory and hemodynamic effects of cefazolin, ceftriaxone, enrofloxacin, and ampicillin in cats anesthetized with isoflurane.

\section{MATERIALS AND METHODS}

This study was approved by the Ethics Committee on Animal Use of the School of Agrarian and Veterinary Sciences, São Paulo
State University, Jaboticabal, São Paulo State, with protocol number $017178 / 13$. Fifty mixed breed adult female cats, 2.5 and $3.2 \mathrm{~kg}$ of body weight, were subjected to physical examination, hemogram, and biochemical analysis (ALT and creatinine) and only those considered healthy were included in the study. Once the experimental data was collected, the cats were subjected to minimally invasive ovariohysterectomy (OSH), as consented by the owners.

The animals were distributed into five groups $(n=10)$ and subjected to intravenous injections, of different antimicrobial drugs according to their treatment group: GP (placebo group), saline solution $(0.9 \% \mathrm{NaCl}$ - isofarma - Brazil); G2 (cefazolin group), 22mg $\mathrm{kg}^{-1}$ cefazolin (Cefazolina - Eurofarma - Brazil); G3 (ceftriaxone group), 22mg kg $\mathrm{kg}^{-1}$ ceftriaxone (Ceftriaxona - Eurofarma - Brazil); G4 (enrofloxacin group), 5mg $\mathrm{kg}^{-1}$ enrofloxacin (Enrofloxacino 5\% - Vencofarma - Brazil); and G5 (ampicillin group), 22 $\mathrm{mg} \mathrm{kg}^{-1}$ ampicillin (Ampicilina - Eurofarma - Brazil). This was a blind randomized study and each animal received only one treatment. Volume and administration time were standardized for all groups $(2 \mathrm{~mL}$ in 1minute, based on $0.9 \%$ sodium chloride injection) so as not to affect the results by variations in blood volume or speed of application.

Fasting of solids was introduced 12 hours prior to anesthesia while water was made available until the administration of pre-anaesthetic medication. Animals were pre-medicated with $0.2 \mathrm{mg} \mathrm{kg}^{-1}$ morphine (Dimorf - Cristália - Brazil) and $0.05 \mathrm{mg} \mathrm{kg}^{-1}$ acepromazine (Acepran $0.2 \%$ Vetnil - Brazil), intramuscularly. After 45 minutes, an intravenous catheter was placed in the cephalic vein for the administration of antimicrobial drugs and fluid therapy with Ringer Lactate (Ringer solution with lactate Baxter - Brazil) at $10 \mathrm{~mL} \mathrm{~kg}^{-1}$ hour ${ }^{-1}$.

Anesthesia was induced using a combination of $0.25 \mathrm{mg} \mathrm{kg}^{-1}$ diazepam (Compaz - Cristália Brazil) and $5 \mathrm{mg} \mathrm{kg}^{-1}$ ketamine (Quetamina Vetnil - Brazil). The cats were intubated with endotracheal tube of appropriate diameter and connected to a non-rebreathing circuit (Baraka) for maintenance of the anesthetic plane. The animals were placed in dorsal decubitus for 
surgical preparation. Anesthesia was maintained using $1 \%$ isoflurane (Forane - Abbott - Brazil) through a calibrated vaporizer (Pfill Selectatec Calibrated Vaporizer, Isoflurane model Takaoka - Brazil) under spontaneous ventilation and which remained constant throughout the whole experimental period.

A 24-gauge catheter (BD Angiocath - BD Brazil) was placed in the coccygeal artery for direct monitoring of arterial pressure. Systolic (SAP), mean (MAP), and diastolic (DAP) arterial pressures were continuously monitored by a transducer connected to a multiparameter monitor (Dixtal 2010 -Dixtal - Brazil). Heart rate (HR), respiratory rate (RR), oxygen saturation $\left(\mathrm{SpO}_{2}\right)$, expired total carbon dioxide $\left(\mathrm{ETCO}_{2}\right)$, and body temperature (BT) were also monitored. Once stage III of anesthesia was reached, all parameters were recorded (T0). Immediately after, $2 \mathrm{~mL}$ saline $(0.9 \% \mathrm{NaCl}) ; 5 \mathrm{mg} \mathrm{kg} \mathrm{kg}^{-1}$ enrofloxacin; and $22 \mathrm{mg} \mathrm{kg}^{-1}$ ceftriaxone, ampicillin, or cefazolin were administered intravenously according to the treatment groups. HR (bpm), RR (mpm), SAP (mmHg), mAP $(\mathrm{mmHg}), \quad \mathrm{DAP}(\mathrm{mmHg}), \mathrm{SpO}_{2}(\%), \mathrm{ETCO}_{2}$ $(\mathrm{mmHg})$, and BT $\left({ }^{\circ} \mathrm{C}\right)$ were recorded at 5 (T5), 10 (T10), 15 (T15), 20 (T20), 25 (T25), and 30 (T30) minutes after administration of the antimicrobial drugs.

Once the parameters were recorded at T30, animals were subjected to minimally invasive $\mathrm{OSH}$ using the technique described by Pukacz et al. (2009).meloxicam $\left(0.05 \mathrm{~m} \mathrm{~kg}^{-1}, \mathrm{IV}\right)$ was given prior to extubating (Maxicam - Ouro Fino Brazil) and tramadol chlorhydrate $\left(2 \mathrm{mg} \mathrm{kg}^{-1}, \mathrm{IV}\right)$ (Tramadon - Cristália - Brazil) administered 4 hours after morphine injection (pre-medication).
The variables were tested by split-plot in a completely randomized design, with Group (5 levels) as a factor in the plot and Time (7 levels) as a factor in the sub-plots. If the means were significantly different, these were compared by the Tukey's test. Analysis was performed using the General Linear Model (GLM) of the statistical software SAS (SAS 9.1, SAS Institute, Cary. NC, USA). Differences were considered significant at $\mathrm{P} \leq 0.05$.

\section{RESULTS}

No complications were observed during anesthesia or surgery. The animals were monitored for at least 3 hours post-surgery and discharged without antimicrobial prescription during the recovery period. Analysis among the groups at each sampling time showed that, when compared to the control group, $\mathrm{ETCO}_{2}$ was significantly $(\mathrm{P} \leq 0.05)$ higher in $\mathrm{G} 2$ and $\mathrm{G} 5$ at all times (T0 to T30) (Table 1); HR was significantly $(\mathrm{P} \leq 0.05)$ lower in $\mathrm{G} 2$ at T5, T10, T15, T25, and T30 (Table 2); and BT was significantly $(\mathrm{P} \leq 0.05)$ higher in $\mathrm{G} 3$ at $\mathrm{T} 0$ and T5 (Table 3). Analysis among times within each group showed that, when compared to T0, there was a significant $(\mathrm{P} \leq 0.05)$ reduction in $\mathrm{HR}$ in G4 at T25 and T30 (Table 2); and a reduction (P $\leq 0.05$ ) in BT in GP from T20 to T30, in G2 and G3 from T15 to T30, and in G4 and G5 from T10 to T30 (Table 3).

No significant $(\mathrm{P}>0.05)$ differences were observed in $\mathrm{SpO}_{2}, \mathrm{RR}, \mathrm{SAP}, \mathrm{mAP}$, and DAP in any of the groups.

Table 1. $\mathrm{ETCO}_{2}(\mathrm{mmHg})$ parameter comparing the experimental groups (GP, G2, G3, G4, G5) at each time (T0, T5, T10, T15, T20, T25 and T30) in cats anesthetized with isoflurane, submitted to the perioperative application of antimicrobials in the prophylactic modality

\begin{tabular}{cccccccc} 
& T0 & T5 & T10 & T15 & T20 & T25 & T30 \\
\hline GP & $29.1 \pm 5.8$ & $27.7 \pm 5.1$ & $27.5 \pm 5.0$ & $27.0 \pm 5.0$ & $28.4 \pm 5.5$ & $28.6 \pm 6.3$ & $28.9 \pm 6.4$ \\
G2 & $40.3 \pm 6.6^{*}$ & $45.0 \pm 7.5^{*}$ & $45.0 \pm 8.2^{*}$ & $44.8 \pm 7.7^{*}$ & $44.5 \pm 6.6^{*}$ & $43.6 \pm 6.9^{*}$ & $43.5 \pm 6.7^{*}$ \\
G3 & $28.1 \pm 5.6$ & $29.7 \pm 5.6$ & $30.1 \pm 5.4$ & $28.9 \pm 5.1$ & $29.5 \pm 5.0$ & $27.3 \pm 5.5$ & $28.1 \pm 6.7$ \\
G4 & $28.6 \pm 5.1$ & $27.0 \pm 7.3$ & $27.9 \pm 7.7$ & $27.0 \pm 7.5$ & $26.0 \pm 7.5$ & $27.6 \pm 8.2$ & $26.6 \pm 6.9$ \\
G5 & $36.5 \pm 10.1^{*}$ & $35.9 \pm 6.7^{*}$ & $36.2 \pm 7.1^{*}$ & $35.6 \pm 6.8^{*}$ & $36.4 \pm 5.9^{*}$ & $35.9 \pm 6.9^{*}$ & $37.2 \pm 5.1^{*}$
\end{tabular}

Data presented as mean \pm standard deviation. *difference of groups in relation to GP at each moment $(\mathrm{P} \leq 0.05) .{ }^{*}$ time difference in relation to $\mathrm{T} 0$ in each group $(\mathrm{P} \leq 0.05)$. 
Table 2. HR (bpm) parameter comparing the experimental groups (GP, G2, G3, G4, G5) at each time (T0, T5, T10, T15, T20, T25 and T30) in cats anesthetized with isoflurane, submitted to the perioperative application of antimicrobials in the prophylactic modality

\begin{tabular}{|c|c|c|c|c|c|c|c|}
\hline & T0 & T5 & $\mathrm{T} 10$ & $\mathrm{~T} 15$ & $\mathrm{~T} 20$ & $\mathrm{~T} 25$ & T30 \\
\hline GP & $142.0 \pm 16.6$ & $142.4 \pm 19.5$ & $143.1 \pm 24.8$ & $139.3 \pm 27.8$ & $133.9 \pm 28.3$ & $136.9 \pm 26$ & $134.5 \pm 26.5$ \\
\hline $\mathrm{G} 2$ & $130.0 \pm 20.7$ & $118.5 \pm 18.3^{*}$ & $117.2 \pm 14 *$ & $115.7 \pm 18.8^{*}$ & $114.8 \pm 15.2$ & $115.5 \pm 16^{*}$ & $112.2 \pm 16.3 *$ \\
\hline G3 & $146.1 \pm 22.4$ & $137.0 \pm 22$ & $133.2 \pm 21.3$ & $138.6 \pm 25.1$ & $129.2 \pm 20.8$ & $133.9 \pm 27.8$ & $136.7 \pm 27$ \\
\hline G4 & $150.2 \pm 25$ & $143.2 \pm 24.5$ & $138.1 \pm 24.1$ & $134.7 \pm 26.3$ & $130.2 \pm 27.9$ & $125.4 \pm 24.4^{\#}$ & $117.5 \pm 21.7^{\#}$ \\
\hline G5 & $148.8 \pm 38$ & $140.1 \pm 36.8$ & $134.0 \pm 36.2$ & $133.8 \pm 38$ & $129.7 \pm 36.3$ & $138.4 \pm 40.2$ & $130.6 \pm 35.9$ \\
\hline
\end{tabular}

Data presented as mean \pm standard deviation. *difference of groups in relation to GP at each moment $(\mathrm{P} \leq 0.05) .{ }^{*}$ time difference in relation to $\mathrm{T} 0$ in each group $(\mathrm{P} \leq 0.05)$.

Table 3. BT $\left({ }^{\circ} \mathrm{C}\right)$ parameter comparing the experimental groups (GP, G2, G3, G4, G5) at each time (T0, T5, T10, T15, T20, T25 and T30) in cats anesthetized with isoflurane, submitted to the perioperative application of antimicrobials in the prophylactic modality

\begin{tabular}{cccccccc}
\hline & T0 & T5 & T10 & T15 & T20 & T25 & T30 \\
\hline GP & $36.9 \pm 1$ & $36.8 \pm 1.1$ & $36.7 \pm 1.1$ & $36.6 \pm 1.1$ & $36.4 \pm 1.2^{\#}$ & $36.2 \pm 1.2^{\#}$ & $36.1 \pm 1.1^{\#}$ \\
G2 & $36.9 \pm 0.5$ & $36.9 \pm 0.6$ & $36.7 \pm 0.7$ & $36.4 \pm 0.6^{\#}$ & $36.2 \pm 0.7^{\#}$ & $36.1 \pm 0.7^{\#}$ & $36.0 \pm 0.7^{\#}$ \\
G3 & $37.4 \pm 0.4^{*}$ & $37.3 \pm 0.5^{*}$ & $37.0 \pm 0.6$ & $36.8 \pm 0.6^{\#}$ & $36.7 \pm 0.6^{\#}$ & $36.6 \pm 0.6^{\#}$ & $36.4 \pm 0.6^{\#}$ \\
G4 & $36.9 \pm 0.7$ & $36.8 \pm 0.8$ & $36.5 \pm 0.8^{\#}$ & $36.4 \pm 0.8^{\#}$ & $36.3 \pm 0.8^{\#}$ & $36.2 \pm 0.8^{\#}$ & $35.9 \pm 1^{\#}$ \\
G5 & $36.9 \pm 0.4$ & $36.6 \pm 0.3$ & $36.4 \pm 0.4^{\#}$ & $36.3 \pm 0.4^{\#}$ & $36.1 \pm 0.4^{\#}$ & $36.1 \pm 0.4^{\#}$ & $35.9 \pm 0.5^{\#}$
\end{tabular}

Data presented as mean \pm standard deviation. *difference of groups in relation to GP at each moment $(\mathrm{P} \leq 0.05)$. ${ }^{\#}$ time difference in relation to $\mathrm{T} 0$ in each group $(\mathrm{P} \leq 0.05)$.

\section{DISCUSSION}

Around the 1940s, the start of antimicrobial use led to hospital-borne infections being looked at under a new perspective (Monteiro, 1993). Although drug therapies in cats are often successful, the protocols and therapeutic use of drugs from other species must be applied with care in felines (Souza, 2003). In the present study, G5 and G2 showed an increase in $\mathrm{ETCO}_{2}$ at all times ( $\mathrm{T} 0$ to T30); furthermore, G2 showed a reduction in HR. Although there were significant differences in $\mathrm{ETCO}_{2}$ levels, these remained within the normal range for the species in all treatments. Thus, the higher levels observed were probably due to the fact that anesthetized animals always develop hypoventilation. According to Cunha (2001), pulmonary reactions are uncommon side effects to antimicrobial therapy; therefore, a cause not related to the administration of medicines must be the reason for such effects. The findings from the present study are in agreement with this, as it was shown that the changes occurred from the first sampling time (T0), before antimicrobial treatment was even administered.

All general anesthetics lead to dose-dependent reduction in the response to $\mathrm{CO}_{2}$, resulting in decreased alveolar volume, due predominantly to a reduction in blood volume, and unaltered respiratory rate when the animal is breathing by the spontaneous method (McDonell and Kerr, 2013). According to Costa et al. (2014), animals pre-medicated with morphine showed respiratory depression, which leads to a decrease in the respiratory minute volume and increase in $\mathrm{ETCO}_{2}$. However, McDonell and Kerr (2013) described that hypercapnia is a result of opioid use in pre-anesthesia medication due to high doses being used, which consequently results in the combined depressive effect of opioids and general anesthesia on the respiratory center. As the dose used in the present study was the standard dose routinely used in veterinary practice, the results from this study corroborated these authors, in which opioids used either as a pre-anesthetic, routine drug, or post-operative 
analgesic rarely lead to significant respiratory depression related to hypercapnia.

Several studies have suggested that under certain circumstances antimicrobials can cause cardiovascular depression (Cunha, 2001), as observed in this study by the reduction in HR in G2 and G4. This is probably due to a direct action of the drug on specific physiological functions instead of hypersensitivity or cytotoxic reactions (Cunha, 2001). According to Wright and Pauuw (2013), some antimicrobials can lead to prolonged QT interval due to direct changes in the potassium channels and inhibition of cytochrome enzymes, which are accompanied by ventricular arrhythmias, bradycardia, and hypotension. However, the reduction in HR observed in the present study cannot be attributed to prolonged QT interval as all patients were monitored by electrocardiogram and no alteration in the QT interval was registered.

Chanoit et al. (2005) reported no vascular changes in dogs after marbofloxacin (quinolone) administration at the recommended dose; contrary to the findings of the present study, in which a reduction in HR was observed in G4, suggesting potential effects of enrofloxacin on cardiovascular function. These results, however, cannot be attributed only to antimicrobial use as some anesthetic protocols could lead to dosedependent changes in cardiovascular function. Furthermore, cardiovascular alterations following enrofloxacin administration have only been observed when the dose administered was 6 times greater than that recommended in the literature (Chanoit et al., 2005). These effects from excessive dosage have also been reported in humans and animals for other quinolones, such as levofloxacin, ofloxacin, and norfloxacin (Takayama et al., 1995).

However, it is noteworthy that such experiments were performed on dogs and, given the difference in metabolic physiology with the feline species, it cannot exclude the possibility of the influence of enrofloxacin on the HR of the animals submitted to this study. Maki et al. (1992) when comparing the prophylactic use of cefazolin, vancomycin, and cefamandole against surgical infections in human patients subjected to cardiac or major vascular surgeries, observed that the adverse effects attributed to prophylactic therapy were infrequent in all three groups.
Furthermore, these authors reported that the most prominent side effect observed was the hypotensive effect of vancomycin, which was counteracted by pre-treatment with diphenhydramine. These findings are in disagreement with the results from the present study, in which cefazolin was the antimicrobial that resulted in the longest depression of cardiovascular function, as a reduction in HR was observed throughout the experimental period from the moment of cefazolin administration.

So as not to alter blood volume, and consequently affect arterial pressure, a standardized volume and application time of treatment was established for all groups $(2 \mathrm{~mL}$ in 1minute), based on the administration of $0.9 \%$ sodium chloride. According to Oleskovicz et al. (2009), $0.9 \% \mathrm{NaCl}$ does not cause immediate or definitive changes in hemodynamic parameters and hypertonic sodium chloride solution must be used $(7.5 \% \mathrm{NaCl})$ when these parameters need to be reestablished.

Intravenous anesthetic drugs such as barbituric, ketamine, and propofol; and inhaling anesthetics such as isoflurane, reduce cardiac contractility by decreasing the uptake of calcium by specific channels, thus minimizing calcium release by the sarcoplasmic reticulum and troponin $\mathrm{C}$ sensitivity to calcium, leading to reduced activation of the myofilament, which in turn compromises sarcomere shortening, reducing HR (Muir, 2013). In the present study, although isoflurane was used to promote anesthesia, only two groups showed HR deficit. As all animals were monitored throughout the experimental period, and thus the same anesthetic plane was used, it can be concluded that in at least one group (G2) the effect on HR was caused using antimicrobials and not by isoflurane inhalation.

In agreement with the findings in the present study, Souza et al. (2008) have reported that isoflurane causes a reduction in peripheral vascular resistance, depression of the cardiovascular function, arterial hypotension, and HR reduction. Thus, based on the HR alterations observed in the present study, it is believed that isoflurane may have affected the results in $\mathrm{G} 4$, as the changes occurred at the last third of the experimental phase, highlighting the difference among the times within the same group even though it was not different from GP. These 
findings agree with the fact that isoflurane is a dose-dependent cardiovascular depressor; however, the same was not observed in $\mathrm{G} 2$, as the changes began at T5, with no difference among the times within the same group but different from GP.

Besides isoflurane, the anesthesia protocol also consisted of morphine and acepromazine as sedatives and diazepam and ketamine as induction agents. Opioids tend to have minimal effect on cardiac debit and rhythm. Bradycardia can occur and, in this case, without vagal bulbar stimulation; however, hypotension as a result of histamine release is more common, especially after fast intravenous application (Lamont and Mathews, 2013). On the other hand, the majority of sedatives induce adverse cardiovascular effects. Acepromazine can contribute to significant intra-operative hypotension or bradycardia (Lemke, 2013). In the present study, hypotension was not significant, probably due to the fact that morphine was given intramuscularly and the acepromazine dose was low $\left(0.05 \mathrm{mg} / \mathrm{kg}^{-}\right.$ ${ }^{1}$ ), half of that used by Lemke (2013) in a study with conscious cats, which reported that acepromazine given intramuscularly at $0.1 \mathrm{mg} / \mathrm{kg}$ ${ }^{1}$ reduced mean arterial pressure by $30 \%$ within 10minutes of application and, when given to animals anesthetized with isoflurane, there is a marked decrease in arterial pressure.

Diazepam promotes the majority of its pharmacological effects by modulating GABAmediated neurotransmission (gammaaminobutyric acid) and has little effect on cardiovascular and pulmonary function (Robinson and Borer-Weir, 2015). Ketamine causes indirect cardiovascular stimulation through centrally mediated sympathomimetic effects, inhibition of neuronal uptake of catecholamines at sympathetic nerve endings, and inotropic effect on the myocardium (Lin, 2013). It is believed that the stimulatory effects of ketamine in the present study were attenuated by pre-medication with acepromazine and by its association with diazepam at the time of anesthesia induction (Reich and Silvay, 1989), thus leading to stability of cardiovascular and hemodynamic functions in the animals evaluated, in agreement with the findings by Farver et al. (1986).

In summary, anesthesia can cause cardiovascular changes even in healthy patients, either by the combination of drugs or by the methods used to maintain an adequate anesthesia plane (Moorer et al., 2013). The use of the anesthesia protocol in the present study aimed at not causing hemodynamic changes that could compromise results, and GP was used to exclude potential changes in the vital parameters caused by anesthesia.

Body temperature (BT) was altered in all treatment groups. When compared to GP, G3 showed an increase at $\mathrm{T} 0$ and $\mathrm{T} 5$. When compared to $\mathrm{T} 0$, all groups showed a reduction, including GP. Although significantly different, the values of BT remained within the normal range for the species in all animals. Hypothermia can occur in anaesthetized animals and central body temperatures of up to $36^{\circ} \mathrm{C}$ are not harmful to the patient (Haskins, 2013). Opioids directly affect the hypothalamic thermoregulatory system and hypothermia tends to be the most common outcome (Lamont and Mathews, 2013). According to Haskins (2013), hypothermia during anesthesia can be related to a reduction in muscle activity caused by anesthetic drugs, metabolism, and thermostatic mechanisms of the hypothalamus. The BT values of G3, which were above those of GP, were within normal range $\left(37.4^{\circ} \mathrm{C}\right.$ and $\left.37.3^{\circ} \mathrm{C}\right)$ and it is believed that this difference may have occurred due to particular factors of each individual as well as external factors, such as room temperature.

\section{CONCLUSION}

It can be concluded that the antimicrobials analyzed did not cause, during the period studied (perioperative), cardiorespiratory or hemodynamic changes that would not permit their use in cats. Under the conditions of this study, it is possible to conclude that ceftriaxone is the safest antimicrobial to be used as a prophylactic in felines as it did not cause significant changes in the variables evaluated (HR, RR, SAP, DAP, and mAP) following intravenous administration ,however the other antimicrobials are also indicated, because all the parameters, in all groups, basically did not change over the study and when this occur it remain in reference interval. Furthermore, it was possible to verify that cefazolin promoted a reduction in heart rate after five minutes of administration. 


\section{ACKNOWLEDGMENTS}

The authors would like to thank the São Paulo State Research Support Foundation (FAPESP Process number 13/18096-4) for the scientific initiation scholarship (RCC) and the National Council for Scientific and Technological Development (CNPq) for the master's scholarship (PRGS) awarded and financial support provided.

\section{REFERENCES}

BUSK, P.; JACOBSEN, S.; MARTINUSSEN, T. Administration of perioperative penicillin reduces postoperative serum amyloid a response in horses being castrated standing. Vet. Surg., v.39, p.638-643, 2010.

CHANOIT, G.P.; SCHNEIDER, M.; WOEHRLÉ, F.; LEFEBVRE, H.P. Effect ofmarbofloxacin on cardiovascular variables in healthy isoflurane-anesthetized dogs. Am. J. Vet. Res., v.66, p.2090-2094, 2005.

COSTA, P.F.; MORO, J.V.; ORTIZ, E.M.G.; CHUNG, D.G. et al. Parâmetros ventilométricos e hemogasométricos em cadelas submetidas à ovário-histerectomia, pré-medicadas com tramadol ou morfina e anestesiadas com isofluorano. Rev. Bras. Med. Vet., v.21, p.167172,2014

CUNHA, B.A. Antibiotic's side effects. Med. Clin. N. Am., v.85, p.149-185, 2001.

FARVER, T.B.; HASKINS, S.C.; PATZ, J.D. Cardiopulmonary effects of acepromazine and of the subsequent administration of ketamine in the dog. Am. J. Vet. Res., v.47, p.631-635, 1986.

HASKINS S.C. Monitoração de pacientes anestesiados. In: TRANQUILI W.J.; THURMON J.C.; GRIMM K.A. (Eds.). Lumb \& Jones' Veterinary anesthesia and analgesia. 4.ed. Ames, Iowa: Blackwell Publishing, 2013. p.582-611

LAMONT, L.A.; MATHEWS, K.A. Opióides, anti-inflamatórios não esteroidais e analgésicos adjuvantes. In: TRANQUILI, W.J.; THURMON, J.C.; GRIMM, K.A. (Eds.). Lumb \& Jones' Veterinary anesthesia and analgesia. 4.ed. Ames, Iowa: Blackwell Publishing, 2013. p.270305.
LANGER, M. Perioperative antibiotic prophylaxis in adults: the 2008 update of the Italian Guidelines. How can we as anesthetists contribute to the reduction of surgical site infections? Minerva Anestesiol., v.75, p.540-542, 2009.

LEMKE, K.A. Opióides, anti-inflamatórios não esteroidais e analgésicos adjuvantes. In: Lumb \& Jones. Anestesiologia e analgesia veterinária. 4.ed. São Paulo: Roca, 2013. cap. 10, p.13-171.

LIN, H.C. Anestésicos dissociativos. In: TRANQUILI W.J.; THURMON J.C.; GRIMM K.A. (Eds.). Lumb \& Jones' Veterinary anesthesia and analgesia. 4.ed. Ames, Iowa: Blackwell Publishing, 2013. p.131-171.

MAKI, D.G.; BOHN, M.J.; STOLZ, S.M.; KRONCKE, G.M. et al. Comparative study of cefazolin, cefamandole, and vancomycin for surgical prophylaxis in cardiac and vascular operations. A double-blind randomized trial. J. Thoracic Cardiovas. Surg. v.104, p.1423-1434, 1992.

McDONELL, W.N.; KERR, K.L. Sistema respiratório. In: TRANQUILI W.J.; THURMON J.C.; GRIMM K.A. (Eds.). LUMB \& Jones' Veterinary anesthesia and analgesia. 4.ed. Ames, Iowa: Blackwell Publishing, 2013. p.131171.

MONTEIRO, J.A. Infecções nosocomiais. Alguns aspectos. Acta Med. Port., v.6, p.135140, 1993.

MOORER, J.D.; TOWLE-MILLARD, H.A.; GROSS, M.E.; PAYTON, M.E. Effects of ampicillin/sulbactam and enrofloxacin on the blood pressure of isoflurane anesthetized dogs. $J$. Am. Anim. Hosp. Assoc., v.49, p.293-300, 2013.

MUIR, W.W. Sistema cardiovascular. In: TRANQUILI W.J.; THURMON J.C.; GRIMM K.A. (Eds.). Lumb \& Jones' Veterinary anesthesia and analgesia. 4.ed. Ames, Iowa: Blackwell Publishing, 2013.p.69-131.

NASCIMENTO, J.W.L.; OMOSAKO, C.E.; CARMONA, M.J. AULER JUNIOR, J.O. et al. Micrométodo para quantificação de cefuroxima em plasma através da cromatografia líquida de alta eficiência. Aplicação na profilaxia de pacientes submetidos à cirurgia cardíaca. Rev. Bras. Ciên. Farmacêut., v.39, p.265-272, 2003. 
OLESKOVICZ, N.; MORENO, J.C.D.; GUIRRO, E.C.P. VALADÃO, C.A.A. et al. Efeitos cardiovasculares da anestesia dissociativa na reposição volêmica com colóide e solução hipertônica em cães: avaliação biotelemétrica. Arq. Bras. Med. Vet. Zootec., v.61, p.27-34, 2009.

PUKACZ, M.; KIENZLE, B.; BRAUM, J. Simpleminimally invasive technique for ovariohysterectomy in the dog. Vet. Rec., v.165, p.688-690, 2009.

RATTI, R.P.; SOUSA, C.P. Staphylococcus aureusmeticilina resistente (MRSA) e infecções nosocomiais. Rev. Ciênc. Farmacêut. Bás. Aplic., v.30, p.137-143, 2009.

REICH, D.L.; SILVAY, G. Ketamine: an update on the first twenty-five years of clinical experience. Can. J. Anesthesiol., v.36, p.186197, 1989.

ROBINSON, R.; BORER-WEIR, K. The effects of diazepam ormidazolam on the dose of propofol required to induce anesthesia in cats. Vet. Anaesth. Analg., v.42, p.493-501, 2015.
SANTOS, W.G.; DINIZ, R.C.; CARVALHO I.A.; FREITAS P.M.C.F. Infecção hospitalar em medicina veterinária. Rev. Vet. Zootec., v.21, p.10-15, 2012.

SOUZA, H.J.M. Coletânea em medicina $e$ cirurgia felina. Rio de Janeiro: L.F. Livros, 2003. p.475.

SOUZA, H.J.M.; AMORIM, F.V. terapêutica felina: cuidado como uso de fármacos em gatos. In: ANDRADE S.F. Manual de terapêutica veterinária. 3.ed. São Paulo: Roca, 2008. p.648659.

SOUZA, M.G.; CARARETO, R.; De-NARDI, A.B.; BRITO, F.L.C. et al. Effects of isoflurane on echocardiographic parameters in healthy dogs. Vet. Aesth. Analg., v.35, p.185-190, 2008.

TAKAYAMA, S.; HIROHASHI, M.; KATO, M.; SHIMADA, H. Toxicity of quinolone antimicrobial agents. J. Toxicol. Environ. Health, v.45, p.1-45, 1995.

WRIGHT, J.; PAUUW, D.S. Complications of antibiotics therapy. Med. Clin. N. Am., v.97, p.667-679, 2013. 